\title{
PENGARUH MODEL PEMBELAJARAN DAN KEMAMPUAN AWAL TERHADAP PEMAHAMAN KONSEP DAN MOTIVASI BELAJAR PESERTA DIDIK KELAS $X$ SMA NEGERI 1 MANIANGPAJO (STUDI PADA MATERI POKOK LARUTAN ELEKTROLIT DAN NONELEKTROLIT)
}

\author{
Hasrida, Muhammad Danial ${ }^{1}$, Pince Salempa ${ }^{2}$ \\ ${ }^{1,2}$ Dosen Program Pascasarjana Universitas Negeri Makassar \\ Email: chida20@ymail.com
}

\begin{abstract}
ABSTRAK
Penelitian ini bertujuan untuk mengetahui: (1) ada tidaknya pengaruh model pembelajaran inkuiri terbimbing dan model pembelajaran discovery learning terhadap pemahaman konsep peserta didik; (2) ada tidaknya pengaruh model pembelajaran inkuiri terbimbing dan model pembelajaran discovery learning terhadap motivasi belajar peserta didik; (3) ada tidaknya pengaruh kemampuan awal tinggi dan rendah terhadap pemahaman konsep peserta didik; (4) ada tidaknya pengaruh kemampuan awal tinggi dan rendah terhadap motivasi belajar peserta didik; (5) ada tidaknya interaksi antara model pembelajaran inkuiri terbimbing dan model pembelajaran discovery learning dengan kemampuan awal tinggi dan rendah terhadap pemahaman konsep peserta didik; (6) ada tidaknya interaksi antara model pembelajaran inkuiri terbimbing dan model pembelajaran discovery learning dengan kemampuan awal tinggi dan rendah terhadap motivasi belajar peserta didik. Penelitian ini merupakan penelitian eksperimen semu (quasi eksperiment) dengan desain faktorial $2 \times 2$. Populasi penelitian adalah seluruh peserta didik kelas X SMA Negeri 1 Maniangpajo. Pengambilan sampel dilakukan dengan random sampling dan kelas yang terpilih adalah kelas X.2 dan kelas X.3. Pengujian hipotesis dilakukan dengan program SPSS menggunakan analisis statistik deskriptif dan inferensial. Hasil penelitian menunjukkan bahwa: (1) ada pengaruh model pembelajaran inkuiri terbimbing dan model pembelajaran discovery learning terhadap pemahaman konsep peserta didik; (2) ada pengaruh model pembelajaran inkuiri terbimbing dan model pembelajaran discovery learning terhadap motivai belajar peserta didik; (3) ada pengaruh kemampuan awal tinggi dan rendah terhadap pemahaman konsep peserta didik; (4) ada pengaruh kemampuan awal tinggi dan rendah terhadap motivasi belajar peserta didik; (5) tidak ada interaksi antara model pembelajaran dan kemampuan awal terhadap pemahaman konsep peserta didik; (6) tidak ada interaksi antara model pembelajaran dan kemampuan awal terhadap motivasi belajar peserta didik.
\end{abstract}

Kata Kunci: Inkuiri Terbimbing, Discovery Learning, Pemahaman Konsep, Motivasi Belajar.

\begin{abstract}
The research aimed at examining: (1) whether there is influence of guided inquiry learning model and discovery learning model on students' concept understanding, (2) whether there is influence of guided inquiry learning and discovery learning model on students' learning motivation, (3) whether there is influence of high and low initial ability on students' concept understanding, (4) whether there is influence of high and low initial ability on students' learning motivation, (5) whether there is interaction between guided inquiry learning model and discovery learning model with high and low initial ability on students' concept understanding, and (6) whether there is interaction between guided inquiry model and discovery learning model with high and low initial ability on students' learning motivation. The study is quasi experiment research with $2 \times 2$ factorial design. The population were all class X students at SMA Negeri 1 Maniangpajo. The samples were selected by employing
\end{abstract}


random sampling techniques and obtained class X.2 and class X.3. The hypothesis test was conducted using SPSS program with statistic descriptive analysis and inferential analysis. The result of the study reveal that (1) there I influence of guided inquiry learning model and discovery learning model on students' concept understanding, (2) there is influence of guided inquiry learning and discovery learning model on students' learning motivation, (3) there is influence of high and low initial ability on students' concept understanding, (4) there is influence of high and low initial ability on students' motivation learning, (5) there is no interaction between learning model with initial ability on students' learning motivation.

Keyword: guided inqutiry, discovery learning, concept understanding, learning motivation.

\section{PENDAHULUAN}

Pendidikan merupakan usaha sadar yang sengaja dirancang untuk mencapai tujuan yang telah ditetapkan. Salah satu tujuan pendidikan yaitu untuk meningkatkan kualitas sumber daya manusia. Oleh karena begitu besarnya peran pendidikan terhadap kemajuan suatu bangsa maka kualitas pendidikan perlu ditingkatkan. Pencapaian kualitas yang baik dalam sistem pendidikan bergantung pada tiga hal yaitu: pendidik, kurikulum, dan sarana. Ketiga hal tersebut sudah semestinya ditingkatkan bersama-sama untuk mencapai pendidikan yang bermutu (Nuh, 2014).

Penerapan Kurikulum Tingkat Satuan Pendidikan (KTSP) menginginkan proses pembelajaran yang lebih berpusat pada peserta didik untuk mengembangkan kreativitas, menciptakan kondisi yang menyenangkan, menantang dan kontekstual. Oleh sebab itu, dibutuhkan strategi, metode, model, dan pendekatan pembelajaran bagi pengajar supaya peserta didik dapat belajar secara efektif dan efisien. Guru perlu menyajikan pembelajaran yang menarik dan menyenangkan kepada peserta didik, agar materi yang disampaikan dapat ditangkap, dipahami konsep-konsepnya, dimengerti dan digunakan oleh peserta didik dengan baik agar tujuan pembelajaran dapat tercapai dan diperoleh hasil belajar yang maksimal.

Salah satu unsur yang berperan penting dalam keberhasilan proses pembelajaran yaitu penggunaan model pembelajaran. Melalui model pembelajaran guru dapat membantu peserta didik mendapatkan informasi, ide, keterampilan, cara berpikir, dan mengeksplorasi ide. Oleh karena model pembelajaran meliputi serangkaian kegiatan yang telah dirancang dan direncanakan sedimikian rupa secara sistematis agar tujuan pembelajaran dapat tercapai (Sudjana, 2011). Guru dalam membuat suatu perencanaan pembelajaran harus mampu untuk memilih dan menentukan model pembelajaran yang sesuai dengan materi yang dibelajarkankan. Ketidaksesuaian antara materi dan model pembelajaran akan menyebabkan kurang maksimalnya proses pembelajaran, sehingga akan sangat berpengaruh pada hasil belajar peserta didik. Oleh karena itu, guru harus mampu memilih model pembelajaran yang sesuai dalam proses pembelajaran.

Motivasi belajar yang dimiliki peserta didik dalam setiap kegiatan pembelajaran sangat berperan untuk menigkatkan prestasi belajar peserta didik dalam mata pelajaran tertentu (Nashar, 2004). Peserta didik yang bermotivasi tinggi dan pemilihan model pembelajaran yang tepat dalam suatu proses kegiatan pembelajaran memungkinkan akan memperoleh hasil belajar yang tinggi pula, artinya semakin tinggi motivasinya, semakin tinggi intensitas usaha dan upaya yang dilakukan dalam pembelajaran. Dengan adanya motivasi, peserta didik akan belajar lebih keras, ulet, tekun dan memiliki konsentrasi penuh dalam mengikuti pembelajaran. Oleh karena itu, 
dorongan motivasi belajar merupakan salah satu yang perlu dibangkitkan dalam upaya pembelajaran di sekolah.

Berdasarkan hasil wawancara dengan guru kimia kelas $\mathrm{X}$ SMA Negeri 1 Maniangpajo terhadap pelaksanaan proses pembelajaran menyatakan bahwa sekolah ini masih menerapkan kurikulum KTSP. Namun penerapannya belum sepenuhnya terlaksana. Model yang digunakan guru dalam pembelajaran masih berpusat pada guru (teacher centered) dan kurang melibatkan peserta didik aktif dalam proses pembelajaran. Hal ini berdampak pada kemampuan memahami konsep, motivasi belajar, dan hasil belajar peserta didik sebagian besar masih rendah. Hal ini berdasarkan dari data yang diperoleh di sekolah tersebut tentang KKM yang harus dicapai oleh peserta didik yaitu 77 untuk materi larutan elektrolit dan nonelektrolit. Hasil ulangan harian peserta didik di kelas sekitar 35\% dari jumlah keseluruhan peserta didik yang memperoleh nilai lebih atau sama dengan nilai KKM. Ini berarti peserta didik yang belum mencapai KKM masih ada sekitar $65 \%$. Selain wawancara terhadap guru kimia, juga dilakukan observasi proses pembelajaran di kelas dan wawancara beberapa peserta didik, sehingga diperoleh informasi berikut. Pada umumnya peserta didik antusias untuk mengikuti proses pembelajaran ketika mereka merasa pelajaran tersebut mudah untuk dipahami. Setiap pokok bahasan dalam materi kimia saling terkait satu sama lainnya, sehingga peserta didik yang memiliki pengetahuan prasyarat yang kurang akan merasa kesulitan dalam menerima pelajaran (pengetahuan baru). Akibatnya motivasi belajarnya menurun, yang dapat diidentifikasi dari aktivitas belajar pada saat proses pembelajaran berlangsung yang kurang antusias. Oleh karena itu dalam pembelajaran kimia, pemahaman konsep dapat berpengaruh terhadap motivasi belajar peserta didik. Dengan demikian, diperlukan suatu model pembelajaran inovatif yang mampu melibatkan peserta didik secara aktif sehingga peserta didik dapat bersemangat belajar dan mengembangkan kemampuan berpikirnya untuk menemukan sendiri pengetahuan dan memahami dengan benar konsep yang terkandung dalam materi dan pembelajaranpun menjadi menyenangkan.

Salah satu model pembelajaran yang dapat digunakan adalah model inkuiri terbimbing. Pembelajaran inkuiri terbimbing diterapkan agar peserta didik bebas mengembangkan konsep yang dipelajari bukan hanya sebatas materi yang dicatat saja kemudian dihafal (Yulianingsih \& Hadisaputro, 2013). Model inkuiri terbimbing dapat meningkatkan pemahaman konsep dan motivasi belajar karena peserta didik dilibatkan secara aktif dalam melakukan investigasi. Sebagaimana penelitian yang dilakukan Sochibin, dkk (2009) bahwa model pembelajaran inkuiri terbimbing dapat meningkatkan pemahaman konsep peserta didik. Sintaks model pembelajaran dicantumkan pada Tabel 1.1.

\section{Tabel $1.1 \quad$ Sintaks/Tahap Model} Pembelajaran Inkuiri Terbimbing

\begin{tabular}{|c|c|}
\hline Tahap & Kegiatan Guru \\
\hline $\begin{array}{l}\text { Tahap -1 } \\
\text { Orientasi masalah }\end{array}$ & \begin{tabular}{ll} 
- & \multicolumn{2}{l}{ Menjelaskan } \\
prosedur inkuiri \\
terbimbing dan \\
menyajikan & \\
situasi & yang \\
saling & \\
bertentangan &
\end{tabular} \\
\hline $\begin{array}{l}\text { Tahap -2 } \\
\text { Mengorganisasika } \\
\text { n peserta didik } \\
\text { untuk menemukan } \\
\text { masalah }\end{array}$ & $\begin{array}{l}\text { - } \text { Membimbing } \\
\text { peserta didik } \\
\text { untuk memeriksa } \\
\text { hakikat obyek dan } \\
\text { kondisi yang } \\
\text { dihadapi didik } \\
\text { - Membimbing } \\
\text { peserta mang } \\
\text { untuk memeriksa } \\
\text { masalah yang } \\
\text { ditampilkan }\end{array}$ \\
\hline $\begin{array}{l}\text { Tahap -3 } \\
\text { Mengkaji data dan }\end{array}$ & $\begin{array}{l}\text { - Membimbing } \\
\text { peserta didik }\end{array}$ \\
\hline
\end{tabular}




\begin{tabular}{|c|c|}
\hline eksperimentasi & $\begin{array}{l}\text { untuk melakukan } \\
\text { suatu kegiatan } \\
\text { penyelidikan, } \\
\text { merumuskan } \\
\text { hipotesis, dan } \\
\text { diskusi untuk } \\
\text { informasi yang } \\
\text { diperlukan }\end{array}$ \\
\hline $\begin{array}{l}\text { Tahap -4 } \\
\text { Mengembangkan } \\
\text { dan } \\
\text { mempresentasikan } \\
\text { hasil kegiatan }\end{array}$ & $\begin{array}{l}\text { - Membingbing } \\
\text { peserta didik untuk } \\
\text { mempersentasikan } \\
\text { hasil pengamatan } \\
\text { dan penyelidikan } \\
\text { atau diskusi } \\
\text { mereka hingga } \\
\text { merumuskan } \\
\text { kesimpulan } \\
\end{array}$ \\
\hline $\begin{array}{l}\text { Tahap -5 } \\
\text { Mengevaluasi } \\
\text { kajian } \\
\text { penyelidikan/peng } \\
\text { amatan dari } \\
\text { membuat } \\
\text { rangkuman }\end{array}$ & $\begin{array}{l}\text { - Mengevaluasi } \\
\text { kegiatan } \\
\text { penyelidikan/pen } \\
\text { gamatan, } \\
\text { membimbing } \\
\text { peserta didik } \\
\text { membuat } \\
\text { rangkuman dan } \\
\text { memberikan tugas } \\
\text { mandiri }\end{array}$ \\
\hline
\end{tabular}

Sumber: Joyce \& Weil (2002).

Selain model pembelajaran inkuiri terbimbing, model pembelajaran discovery learning juga dapat digunakan untuk mengatasi permasalahan pembelajaran di atas. Pembelajaran dengan menggunakan discovery learning dapat melibatkan secara aktif peserta didik dalam proses pembelajaran melalui sintaks yang tercantum pada Tabel 2.1.

Tabel 2.2 Sintaks/Tahap Model Pembelajaran Discovery Learning

\begin{tabular}{llr}
\hline \multicolumn{1}{c}{ Tahap } & \multicolumn{2}{c}{ Kegiatan Guru } \\
\hline Tahap -1 & Memulai & kegiatan \\
Stimulasi/pe & pembelajaran dengan \\
mberian & mengajukan pertanyaan, \\
rangsangan & anjuran membaca buku, \\
& dan aktivitas belajar \\
& lainnya yang mengarah \\
& pada persiapan pemecahan \\
& masalah \\
\hline Tahap-2 & Memberikan kesempatan \\
\hline
\end{tabular}

\begin{tabular}{|c|c|}
\hline Tahap & Kegiatan Guru \\
\hline $\begin{array}{l}\text { Pernyataan/i } \\
\text { dentifikasi } \\
\text { masalah }\end{array}$ & $\begin{array}{l}\text { kepada peserta didik untuk } \\
\text { mengidentifikasi sebanyak } \\
\text { mungkin masalah yang } \\
\text { relevan dengan bahan } \\
\text { pelajaran, kemudian salah } \\
\text { satunya dipilih dan } \\
\text { dirumuskan dalam bentuk } \\
\text { hipotesis (jawaban } \\
\text { sementara atas pertanyaan } \\
\text { masalah). }\end{array}$ \\
\hline $\begin{array}{l}\text { Tahap-3 } \\
\text { Pengump } \\
\text { ulan data }\end{array}$ & $\begin{array}{l}\text { - Membimbing peserta didik } \\
\text { untuk mengumpulkan } \\
\text { data melalui eksperimen } \\
\text { atau eksplorasi sehingga } \\
\text { peserta didik mampu } \\
\text { membuktikan hipotesis }\end{array}$ \\
\hline $\begin{array}{l}\text { Tahap-4 } \\
\text { Pengolahan } \\
\text { data }\end{array}$ & $\begin{array}{l}\text { - } \text { Membimbing peserta didik } \\
\text { dalam mengolah data dan } \\
\text { informasi yang telah } \\
\text { diperoleh } \\
\text { membaca melalui } \\
\text { mengamati literatur, } \\
\text { wawancara objek, } \\
\text { narasumber, dengan } \\
\text { melakukan uji coba sendiri }\end{array}$ \\
\hline $\begin{array}{l}\text { Tahap-5 } \\
\text { Verikasi }\end{array}$ & $\begin{array}{l}\text { - Membimbing peserta didik } \\
\text { untuk melakukan } \\
\text { pemeriksaan secara cermat } \\
\text { untuk membuktikan benar } \\
\text { atau tidaknya hipotesis } \\
\text { yang telah ditetapkan. }\end{array}$ \\
\hline $\begin{array}{l}\text { Tahap } 6 \\
\text { Menggenera } \\
\text { lisasi }\end{array}$ & $\begin{array}{l}\text { - Membimbing peserta didik } \\
\text { untuk menyimpulkan } \\
\text { berdasarkan hasil } \\
\text { verifikasi }\end{array}$ \\
\hline
\end{tabular}

Sumber: Kemendikbud 2014

Penelitian yang dilakukan oleh Supriyanto (2014) menyatakan bahwa dalam pembelajaran terjadi peningkatan aktivitas dan hasil belajar peserta didik dengan menggunakan penerapan discovery learning. Selain itu, penelitian Widiadnyana, dkk (2014) menunjukkan terdapat perbedaan nilai rata-rata pemahaman konsep secara signifikan antara kelompok peserta didik yang belajar dengan model discovery learning dengan kelompok peserta didik yang belajar dengan model pengajaran langsung. 
Penelitian lain yang dilakukan Rahman, dkk (2014) menyatakan bahwa metode discovery learning dapat meningkatkan pemahaman konsep peserta didik.

Faktor lain yang harus diperhatikan dalam pembelajaran kimia adalah kemampuan awal peserta didik (Ahmad, 2012). Kemampuan awal peserta didik merupakan salah satu peran penting dalam kelancaran suatu kegiatan pembelajaran karena menggambarkan kesiapan peserta didik dalam menerima pelajaran yang akan disampaikan. Menurut Uno (2010), bahwa kemampuan awal merupakan hasil belajar yang didapat sebelum mendapat kemampuan yang lebih tinggi. Kemampuan awal peserta didik penting untuk diketahui guru sebelum memulai pembelajaran, karena dengan demikian dapat diketahui apakah peserta didik telah mempunyai pengetahuan awal yang merupakan prasyarat untuk mengikuti pembelajaran, sejauhmana peserta didik mengetahui materi apa yang akan disajikan (Djamarah, 2000).

Penelitian yang dilakukan Adesoji (2008), menunjukkan bahwa peserta didik dapat memecahkan masalah dengan baik jika mereka memiliki tingkat kemampuan yang tinggi, namun bagi yang memiliki kemampuan rendah juga bisa menyempurnakan kemampuan memecahkan masalah mereka jika mereka diberikan instruksi strategi pemecahan masalah. Penelitian yang dilakukan Herawati (2013) menunjukkan peserta didik dengan kemampuan awal tinggi meraih prestasi belajar baik kognitif, afektif, dan psikomotor lebih tinggi daripada peserta didik dengan kemampuan awal rendah. Selain itu, penelitian yang dilakukan oleh Astuti (2015) mengatakan bahwa terdapat pengaruh kemampuan awal dan minat belajar secara bersama-sama terhadap prestasi belajar.

Pada penelitian ini materi yang digunakan adalah larutan elektrolit dan nonelektrolit yang berisi tentang konsep, namun dapat diamati dalam hal nyata, karena bersifat aplikatif dan menarik yakni dapat diberikan contoh peristiwa yang ada dalam kehidupan sehari-hari misalnya nelayan yang menangkap ikan dengan cara menyetrum. Walaupun demikian, sebagian peserta didik kurang paham dalam proses memecahkan masalah, menganalisis soal dan memahami konsep-konsep serta penerapannya dalam kehidupan seharihari. Hal ini disebabkan karena peserta didik hanya menghafal bukan menemukan sendiri dalam memahami konsep larutan elektrolit dan nonelektrolit. Oleh karena itu, dengan menerapkan model pembelajaran inkuiri terbimbing dan discovery learning diharapkan peserta didik lebih termotivasi dan berperan aktif dalam proses pembelajaran menemukan konsep dari contoh-contoh atau fakta-fakta khusus dari materi yang dibelajarkankan oleh guru.

Berdasarkan uraian di atas, maka dilakukan penelitian dengan judul: "Pengaruh Model Pembelajaran dan Kemampuan Awal terhadap Pemahaman Konsep dan Motivasi Belajar Peserta didik Kelas X SMA Negeri 1 Maniangpajo (Studi pada Materi Pokok Larutan Elektrolit dan Nonelektrolit)".

Adapun hipotesis dalam penelitian meliputi:

1. Ada pengaruh model pembelajaran inkuiri terbimbing dan model pembelajaran discovery learning terhadap pemahaman konsep peserta didik.

2. Ada pengaruh model pembelajaran inkuiri terbimbing dan model pembelajaran discovery learning terhadap motivasi belajar peserta didik.

3. Ada pengaruh kemampuan awal tinggi dan rendah terhadap pemahaman konsep peserta didik.

4. Ada pengaruh kemampuan awal tinggi dan rendah terhadap motivasi belajar peserta didik.

5. Ada interaksi model pembelajaran dengan kemampuan awal tinggi dan rendah peserta didik terhadap pemahaman konsep. 
6. Ada interaksi model pembelajaran dengan kemampuan awal tinggi dan rendah peserta didik terhadap motivasi belajar.

\section{METODE PENELITIAN}

Jenis penelitian yang digunakan dalam penelitian ini adalah quasi experiment (eksperimen semu) dengan desain faktorial (factorial design) yang dikategorikan sebagai desain faktorial $2 \times 2$. Desain penelitian dapat dilihat pada Tabel 2.1.

Tabel 2.1 Matriks rancangan faktorial 2x2 untuk mengetahui pemahaman konsep dan motivasi belajar peserta didik.

\begin{tabular}{ccc}
\hline $\mathrm{A}$ & \multicolumn{2}{c}{$\mathrm{B}$} \\
\cline { 2 - 3 } & $\mathrm{B}_{1}$ & $\mathrm{~B}_{2}$ \\
\hline $\mathrm{A}_{1}$ & $\mathrm{~A}_{1} \mathrm{~B}_{1}$ & $\mathrm{~A}_{1} \mathrm{~B}_{2}$ \\
$\mathrm{~A}_{2}$ & $\mathrm{~A}_{2} \mathrm{~B}_{1}$ & $\mathrm{~A}_{2} \mathrm{~B}_{2}$ \\
\hline
\end{tabular}

Keterangan:

A = Jenis Model Pembelajaran

$\mathrm{A}_{1}=$ Model Pembelajaran Inkuiri Terbimbing

$\mathrm{A}_{2}=$ Model Pembelajaran Discovey Learning

B = Kemampuan Awal

$\mathrm{B}_{1} \quad=$ Kemampuan Awal Tinggi

$\mathrm{B}_{2} \quad=$ Kemampuan Awal Rendah

$\mathrm{A}_{1} \mathrm{~B}_{1}=$ Pemahaman konsep/motivasi belajar peserta didik yang memiliki kemampuan awal tinggi dengan menggunakan model pembelajaran inkuiri terbimbing

$\mathrm{A}_{1} \mathrm{~B}_{2}=$ Pemahaman konsep/motivasi belajar peserta didik yang memiliki kemampuan awal rendah dengan menggunakan model pembelajaran inkuiri terbimbing

$\mathrm{A}_{2} \mathrm{~B}_{1}=$ Pemahaman konsep/motivasi belajar peserta didik yang memiliki kemampuan awal tinggi dengan menggunakan model pembelajaran discovery learning

$\mathrm{A}_{2} \mathrm{~B}_{2}=$ Pemahaman konsep/motivasi belajar peserta didik yang memiliki kemampuan awal rendah dengan menggunakan model pembelajaran discovery learning
Populasi penelitian ini adalah semua peserta didik kelas X SMA Negeri 1 Maniangpajo pada Tahun Ajaran 2016/2017 yang terdiri dari delapan kelas dengan jumlah peserta didik sebanyak 207 orang.

Pengambilan sampel penelitian dilakukan dengan cara random sampling untuk memilih kelas eksperimen 1 dan kelas eksperimen 2, dengan asumsi bahwa populasi bersifat homogen karena pembagian kelas tidak berdasarkan prestasi atau ranking peserta didik. Sampel yang terpilih adalah kelas X.2 dengan jumlah 25 peserta didik dan kelas X.3 dengan jumlah 25 peserta didik.

Teknik pengumpulan data dalam penelitian ini yaitu :

1. Tes kemampuan awal sebanyak 25 item diberikan sebelum memulai proses pembelajaran larutan elektrolit dan nonelektrolit.

2. Pengumpulan data pemahaman konsep peserta didik dikumpulkan melalui pemberian tes dalam bentuk essay sebanyak 6 item. Tes diberikan sebelum (pretest) dan setelah (posttest) proses pembelajaran berlangsung, pada kelas eksprimen yang dibelajarkan dengan model inkuiri terbimbing dan model pembelajaran discovery learning.

3. Pengumpulan data motivasi belajar peserta didik menggunakan angket motivasi belajar skala Likert yang diberikan sebelum dan setelah proses pembelajaran larutan elektrolit dan nonelektrolit. Angket motivasi belajar sebanyak 46 item.

Data yang diperoleh selanjutnya dianalisis secara statistik deskriptif dan statistik inferensial.

\section{HASIL DAN PEMBAHASAN}

\section{Hasil Penelitian}

Hasil penelitian yang disajikan terdiri dari deskripsi pemahaman konsep dan motivasi belajar peserta didik.

Tabel. 4.1 Deskripsi Pemahaman Konsep Peserta Didik yang Dibelajarkan dengan 
Model Pembelajaran Inkuri Terbimbing dan Model Pembelajaran Discovery Learning.

\begin{tabular}{lcc}
\hline \multirow{2}{*}{ Statistik } & \multicolumn{2}{c}{ Nilai pemahaman konsep } \\
\cline { 2 - 3 } & $\begin{array}{c}\text { Kelas inkuiri } \\
\text { terbimbing }\end{array}$ & $\begin{array}{c}\text { Kelas } \\
\text { discovery } \\
\text { learning }\end{array}$ \\
\hline $\mathrm{N}$ & 25 & 25 \\
Mean $(\overline{\mathrm{X}})$ & 72,48 & 79,92 \\
Median $(\mathrm{Md})$ & 78,00 & 84,00 \\
Varians $\left(s^{2}\right)$ & 200,76 & 187,49 \\
Std. Deviasi & 14,17 & 13,69 \\
$(s)$ & 54,00 & 52,00 \\
Range $(\mathrm{R})$ & & \\
Nilai & & \\
minimum & 46,00 & \\
$\left(\mathrm{X}_{\text {min }}\right)$ & & 100,00 \\
Nilai & & \\
maksimum & 100,00 & \\
$\left(\mathrm{X}_{\text {max }}\right)$ & & \\
\hline
\end{tabular}

Tabel. 4.2 Deskripsi Pemahaman Konsep Peserta Didik yang memiliki Kemampuan Awal Tinggi dan Kemampuan Awal Rendah

\begin{tabular}{lcc}
\hline & \multicolumn{2}{c}{ Nilai Pemahaman Konsep } \\
\cline { 2 - 3 } Statistik & $\begin{array}{c}\text { Kemampuan } \\
\text { Awal Tinggi }\end{array}$ & $\begin{array}{c}\text { Kemampuan } \\
\text { Awal } \\
\text { Rendah }\end{array}$ \\
\hline $\mathrm{N}$ & 25 & 25 \\
Mean $(\overline{\mathrm{X}})$ & 86,00 & 70,19 \\
$\begin{array}{l}\text { Median } \\
\text { (Md) }\end{array}$ & 84,00 & 70,00 \\
$\begin{array}{l}\text { Varians }\left(s^{2}\right) \\
\text { Std. }\end{array}$ & 81,78 & 186,49 \\
$\begin{array}{l}\text { Deviasi }(s) \\
\text { Range }(\mathrm{R})\end{array}$ & 9,04 & 13,66 \\
$\begin{array}{l}\text { Nilai } \\
\text { minimum }\end{array}$ & 32,00 & 50,00 \\
$\left(X_{\text {min }}\right)$ & 68,00 & 46,00 \\
$\begin{array}{l}\text { Nilai } \\
\text { maksimum } \\
\left(X_{\text {max }}\right)\end{array}$ & 100,00 & 96,00 \\
\hline
\end{tabular}

Tabel 4.3 Deskripsi Pemahaman Konsep Peserta Didik berdasarkan Kemampuan Awal dan Model Pembelajaran

\begin{tabular}{lllll} 
Kemampuan & Statistik & $\left(\mathrm{B}_{1}\right)$ & $\left(\mathrm{B}_{2}\right)$ & Total \\
\hline
\end{tabular}

\begin{tabular}{llccc}
\hline $\begin{array}{l}\text { Model } \\
\text { pembelajaran }\end{array}$ & & & & \\
\hline$\left(\mathrm{A}_{1}\right)$ & $\mathrm{N}$ & 10 & 15 & 25 \\
& Mean & 83,20 & 65,33 & 72,48 \\
& $\begin{array}{l}\text { Std. } \\
\text { deviasi }\end{array}$ & 9,94 & 11,99 & 14,17 \\
\hline$\left(\mathrm{A}_{2}\right)$ & $\mathrm{N}$ & 9 & 16 & 25 \\
& Mean & 89,11 & 74,75 & 79,92 \\
& Std. & 7,22 & 13,89 & 13,69 \\
\hline Total & Neviasi & 19 & 31 & 50 \\
& Mean & 86,00 & 70,19 & 76,20 \\
& Std. \\
& deviasi & 9,04 & 13,66 & 14,29 \\
\hline & & & & \\
\hline
\end{tabular}

Tabel 4.4 N-Gain Skor Pemahaman Konsep Peserta didik

\begin{tabular}{|c|c|c|c|c|}
\hline \multirow{3}{*}{ Kategori } & \multicolumn{4}{|c|}{ Model Pembelajaran } \\
\hline & \multicolumn{2}{|c|}{$\begin{array}{l}\text { Inkuiri Terbimbing } \\
\text { (orang/\%) }\end{array}$} & \multicolumn{2}{|c|}{$\begin{array}{c}\text { Discovery } \\
\text { Learning } \\
\text { (orang/\%) }\end{array}$} \\
\hline & $\mathrm{B}_{1}$ & $\mathrm{~B}_{2}$ & $\mathrm{~B}_{1}$ & $\mathrm{~B}_{2}$ \\
\hline Tinggi & $8(32 \%)$ & $4(16 \%)$ & $9(36 \%)$ & $8(32 \%)$ \\
\hline Sedang & $2(8 \%)$ & $10(40 \%)$ & 0 & $8(32 \%)$ \\
\hline Rendah & 0 & $1(4 \%)$ & 0 & 0 \\
\hline
\end{tabular}

Tabel. 4.5 Deskripsi Motivasi Belajar Peserta Didik yang Dibelajarkan dengan Model Pembelajaran Inkuri Terbimbing dan Model Pembelajaran Discovery Learning.

\begin{tabular}{|c|c|c|}
\hline \multirow[b]{2}{*}{ Statistik } & \multicolumn{2}{|c|}{ Nilai Motivasi Belajar } \\
\hline & $\begin{array}{c}\text { Kelas inkuiri } \\
\text { terbimbing }\end{array}$ & $\begin{array}{c}\text { Kelas } \\
\text { discovery } \\
\text { learning }\end{array}$ \\
\hline $\mathrm{N}$ & 25 & 25 \\
\hline Mean $(\bar{x})$ & 81,48 & 85,48 \\
\hline Median (Md) & 82,00 & 88,00 \\
\hline Varians $\left(s^{2}\right)$ & 62,43 & 57,26 \\
\hline $\begin{array}{l}\text { Std. Deviasi } \\
(s)\end{array}$ & 7,90 & 7,57 \\
\hline $\begin{array}{l}\text { Range (R) } \\
\text { Nilai }\end{array}$ & 32,00 & 24,00 \\
\hline $\begin{array}{l}\operatorname{minimum} \\
\left(\mathrm{X}_{\min }\right)\end{array}$ & 61,00 & 70,00 \\
\hline $\begin{array}{l}\text { Nilai } \\
\text { maksimum } \\
\left(X_{\max }\right)\end{array}$ & 93,00 & 94,00 \\
\hline
\end{tabular}

Tabel. 4.6 Deskripsi Motivasi Belajar Peserta Didik yang memiliki Kemampuan 
Awal Tinggi dan Kemampuan Awal Rendah

\begin{tabular}{lcc}
\hline \multirow{2}{*}{ Statistik } & \multicolumn{2}{c}{ Nilai Pemahaman Konsep } \\
\cline { 2 - 3 } & $\begin{array}{c}\text { Kemampuan } \\
\text { Awal Tinggi }\end{array}$ & $\begin{array}{c}\text { Kemampuan } \\
\text { Awal } \\
\text { Rendah }\end{array}$ \\
\hline $\mathrm{N}$ & 25 & 25 \\
Mean $(\overline{\mathrm{X}})$ & 86,53 & 81,61 \\
Median & 87,00 & 83,00 \\
$($ Md) & 45,37 & 65,71 \\
$\begin{array}{l}\text { Varians }\left(s^{2}\right) \\
\text { Std. }\end{array}$ & 6,74 & 8,11 \\
$\begin{array}{l}\text { Deviasi }(s) \\
\text { Range }(\mathrm{R})\end{array}$ & 24,00 & 31,00 \\
$\begin{array}{l}\text { Nilai } \\
\text { minimum }\end{array}$ & 70,00 & 61,00 \\
$\left(\mathrm{X}_{\text {min }}\right)$ & & \\
$\begin{array}{l}\text { Nilai } \\
\text { maksimum }\end{array}$ & 94,00 & 92,00 \\
$\left(\mathrm{X}_{\text {max }}\right)$ & & \\
\hline
\end{tabular}

Tabel 4.7 Deskripsi Motivasi Belajar Peserta Didik berdasarkan Kemampuan Awal dan Model Pembelajaran

\begin{tabular}{|c|c|c|c|c|}
\hline $\begin{array}{l}\text { Kemampuan } \\
\quad \text { Awal } \\
\text { Model } \\
\text { Pembelajaran }\end{array}$ & Statistik & $\left(\mathrm{B}_{1}\right)$ & $\left(\mathrm{B}_{2}\right)$ & Total \\
\hline \multirow[t]{3}{*}{$\left(\mathrm{A}_{1}\right)$} & $\mathrm{N}$ & 10 & 15 & 25 \\
\hline & Mean & 84,00 & 79,80 & 81,48 \\
\hline & $\begin{array}{l}\text { Std. } \\
\text { Deviasi }\end{array}$ & 6,73 & 8,38 & 7,90 \\
\hline \multirow[t]{3}{*}{$\left(A_{2}\right)$} & $\mathrm{N}$ & 9 & 16 & 25 \\
\hline & Mean & 89,33 & 83,31 & 85,5 \\
\hline & $\begin{array}{l}\text { Std. } \\
\text { Deviasi }\end{array}$ & 5,85 & 7,71 & 7,57 \\
\hline \multirow[t]{3}{*}{ Total } & $\mathrm{N}$ & 19 & 31 & 50 \\
\hline & Mean & 86,53 & 81,61 & 83,48 \\
\hline & $\begin{array}{l}\text { Std. } \\
\text { Deviasi }\end{array}$ & 6,74 & 8,11 & 7,92 \\
\hline
\end{tabular}

Tabel 4.8 N-Gain Skor Motivasi Belajar Peserta Didik

\begin{tabular}{ccccc}
\hline \multirow{3}{*}{ Kategori } & \multicolumn{3}{c}{ Model Pembelajaran } \\
\cline { 2 - 5 } & $\begin{array}{c}\text { Inkuiri Terbimbing } \\
\text { (orang/\%) }\end{array}$ & \multicolumn{2}{c}{$\begin{array}{c}\text { Discovery } \\
\text { Learning } \\
\text { (orang) }\end{array}$} \\
\cline { 2 - 5 } & $\mathrm{B}_{1}$ & $\mathrm{~B}_{2}$ & $\mathrm{~B}_{1}$ & $\mathrm{~B}_{2}$ \\
\hline Tinggi & $2(8 \%)$ & $1(4 \%)$ & $2(8 \%)$ & $3(12 \%)$ \\
Sedang & $6(24 \%$ & $10(40 \%)$ & $6(24 \%)$ & $8(32 \%)$ \\
\hline
\end{tabular}

\begin{tabular}{lllll}
\hline Rendah & $2(8 \%)$ & $4(16 \%)$ & $1(4 \%)$ & $5(20 \%)$ \\
\hline
\end{tabular}

Tabel 4.9 Kategori Motivasi Belajar Peserta Didik

\begin{tabular}{lcccc}
\hline & \multicolumn{4}{c}{ Model Pembelajaran } \\
\cline { 2 - 5 } Kategori & \multicolumn{2}{c}{$\begin{array}{c}\text { Inkuiri } \\
\text { Terbimbing } \\
\text { (orang/\%) }\end{array}$} & \multicolumn{2}{c}{$\begin{array}{c}\text { Discovery Learning } \\
\text { (orang/\%) }\end{array}$} \\
\cline { 2 - 5 } & $\mathrm{B}_{1}$ & $\mathrm{~B}_{2}$ & $\mathrm{~B}_{1}$ & $\mathrm{~B}_{2}$ \\
\hline Sangat & $5(20 \%)$ & $6(24 \%)$ & $8(32 \%)$ & $9(36 \%)$ \\
Tinggi & & & & \\
Tinggi & $5(20 \%)$ & $8(32 \%)$ & $1(4 \%)$ & $7(28 \%)$ \\
Cukup & 0 & $1(4 \%)$ & 0 & 0 \\
Rendah & 0 & 0 & 0 & 0 \\
Sangat & 0 & 0 & 0 & 0 \\
Rendah & 0 & & & \\
\hline
\end{tabular}

Tabel 4.10 Hasil Uji Normalitas Pemahaman Konsep dan Motivasi Belajar dengan One-Sample-Kolmogorov-Smirnov Test

\begin{tabular}{lrr}
\hline & $\begin{array}{c}\text { pemahaman } \\
\text { konsep }\end{array}$ & $\begin{array}{c}\text { motivasi } \\
\text { belajar }\end{array}$ \\
\hline Kolmogorov-Smirnov & 1,203 &, 883 \\
Z &, 111 &, 417 \\
\hline
\end{tabular}

Tabel 4.11 Hasil Uji Homogenitas Pemahaman Konsep dan Motivasi Belajar dengan Levene Test of Equality of Error Variance

\begin{tabular}{|c|c|c|c|c|}
\hline & $\mathrm{F}$ & df1 & df2 & Sig \\
\hline $\begin{array}{l}\text { pemahaman } \\
\text { konsep }\end{array}$ & 2,420 & 3 & 46 & ,078 \\
\hline motivasi belajar & 1,279 & 3 & 46 & 293 \\
\hline
\end{tabular}

Tabel 4.12 Hasil Pengujian Hipotesis dengan Analisis Two Ways MANOVA 
2. Pembahasan

\section{a. Pengaruh Model Pembelajaran Inkuiri Terbimbing dan Model Pembelajaran Discovery Learning terhadap Pemahaman Konsep Peserta Didik}

Berdasarkan analisis inferensial diperoleh nilai signifikansi $0,029<\alpha$, berarti $\mathrm{H}_{0}$ ditolak dan $\mathrm{H}_{1}$ diterima, sehingga dapat disimpulkan bahwa ada pengaruh model pembelajaran inkuiri terbimbing dan model pembelajaran discovery learning terhadap pemahaman konsep peserta didik kelas X SMA Negeri 1 Maniangpajo pada materi pokok larutan elektrolit dan nonelektrolit.

Nilai rata-rata pemahaman konsep peserta didik yang dibelajarkan dengan model inkuiri terbimbing adalah 72,48, sedangkan model pembelajaran discovery learning adalah 79,92. Hasil tersebut diperoleh bahwa rata-rata pemahaman konsep peserta didik yang dibelajarkan dengan model pembelajaran discovery learning lebih tinggi jika dibandingkan model pembelajaran inkuiri terbimbing. Hal ini berarti model pembelajaran discovery learning lebih baik dibandingkan dengan model pembelajaran inkuiri terbimbing dalam mempengaruhi pemahaman konsep peserta didik. Model pembelajaran discovery learning adalah salah satu model pembelajaran yang berpengaruh terhadap pemahaman konsep peserta didik, karena peserta didik didorong untuk belajar sendiri dalam memahami materi pelajaran yang sedang dipelajari. Kelebihan dari model pembelajaran discovery learning yakni memiliki potensi yang amat besar untuk membuat pengalaman belajar yang lebih menarik dan bermakna bagi peserta didik dalam penemuan konsep. Menurut Bruner pembelajaran yang bermakna akan lebih menanamkan ingatan lebih dalam pada diri peserta didik (Dahar, 2011).

Sesuai dengan karakteristik model pembelajaran discovery learning peserta didik dituntut untuk menemukan suatu konsep atau pengetahuan yang sebelumnya tidak diketahuinya. Untuk menemukan suatu konsep atau pengetahuan yang sebelumnya tidak diketahui, peserta didik diberikan kesempatan untuk mengeksplorasi sendiri pengetahuannya. Peserta didik melakukan eksplorasi dengan melakukan percobaan secara berkelompok. Ketika melakukan percobaan, peserta didik akan berusaha untuk menyelesaikan tugas yang diberikan dan memecahkan permasalahan yang terjadi. Sehingga kemampuan peserta didik dalam memecahkan masalah dengan menggunakan model pembelajaran discovery learning menjadi lebih baik. Hal ini disebabkan karena pada saat proses menemukan akan membuat peserta didik lebih baik pemahamannya terhadap masalah yang dihadapi sehingga membuat peserta didik lebih baik dalam memecahkan masalah kimia. Penelitian ini juga didukung oleh (Rahman, dkk, 2014) menyatakan discovery learning dapat meningkatkan pemahaman konsep peserta didik. Peserta didik mengkaitkan kesamaan konsep yang telah mereka pelajari untuk menemukan konsep baru tentang materi yang sedang dipelajari. Peserta didik yang belajar dengan model discovery learning telah terlatih menemukan konsep baru untuk menyelesaikan masalah.

Selain itu, model ini mampu menciptakan suasana kelas yang demokratis, lingkungan yang saling menghormati, memberi kesempatan pada peserta didik untuk belajar sendiri, berpendapat sendiri, serta berdiskusi mencari jalan keluar dalam menghadapi masalah. Hal ini dapat mengembangkan kemampuan berpikir dan pemahaman konsep peserta didik serta menumbuhkan kepercayaan pada diri sendiri yang kuat yang berdampak pada hasil belajar yang lebih baik.

Penelitian yang relevan dengan hal di atas (Syahputri, dkk, 2016) menyatakan bahwa model pembelajaran discovery learning berpengaruh terhadap hasil belajar peserta didik. Selain itu, hasil penelitian Oghenevwedw (2010) 
menyatakan bahwa model penemuan (discovery) lebih efektif dari penyelidikan (inquiry) dalam mengajar biologi, oleh karena itu guru disarankan menggunakan model ini dalam mengajar untuk penemuan suatu konsep.

\section{b. Pengaruh Model Pembelajaran Inkuiri Terbimbing dan Model Pembelajaran Discovery Learning terhadap Motivasi Belajar Peserta Didik}

Kedua model pembelajaran ini memberikan peningkatan motivasi belajar peserta didik yang terlihat pada nilai $\mathrm{N}$ Gain yang diperoleh, sehingga kedua model pembelajaran tersebut dapat meningkatkan motivasi belajar peserta didik. Model pembelajaran discovery learning memberikan peningkatan yang lebih tinggi, hal ini disebabkan karena model ini memberikan kesempatan yang luas untuk peserta didik dalam mencari dan menemukan sendiri apa yang dibutuhkan untuk memahami dengan baik materi yang dipelajari. selain itu, model ini memberikan kesempatan pada peserta didik untuk bekerja sendiri serta bekerja dengan teman kelompok, sehingga peserta didik lebih banyak beraktivitas untuk menemukan penyelesaian dari permasalahan dan saling membantu dalam proses pembelajaran sehingga meningkatkan motivasi belajar peserta didik karena terlibat secara langsung. Hal inilah yang menyebabkan adanya peningkatan aktivitas pada proses pembelajaran berlangsung yang tentunya akan berpengaruh pula pada peningkatan motivasi belajar peserta didik. Hasil penelitian ini sejalan dengan (Jacobsen, 2009) yang menyatakan bahwa model pembelajaran discovery learning, guru akan lebih sedikit dalan menjelaskan sehingga peserta didik lebih aktif dalam pembelajaran secara kognitif, mendorong pembelajaran dan motivasi.

Model pembelajaran inkuiri terbimbing juga dapat meningkatkan motivasi belajar peserta didik. Pada pelaksanaannya peserta didik memperoleh informasi melalui eksperimen yang dilakukan sehingga dapat memecahkan masalah yang telah dirumuskan secara bersama-sama. Dengan demikian dapat meningkatkan motivasi belajar peserta didik. Hal ini sesuai dengan tujuan utama model pembelajaran inkuiri terbimbing adalah mencari dan menemukan sendiri jawaban dari permasalahan (Sanjaya, 2010). Walaupun model pembelajaran inkuiri terbimbing dan model pembelajaran discovery learning memiliki sintaks yang berbeda, kedua model ini sama-sama dapat meningkatkan motivasi belajar peserta didik karena dalam pelaksanaan kedua model pembelajaran ini melatih peserta didik untuk terlibat langsung dalam mencari dan menemukan penyelesaian dari permasalahan yang dihadapi.

Berdasarkan pada hasil analisis statistic inferensial diperoleh nilai signifikansi $0,048<\alpha$, yang berarti bahwa $\mathrm{H}_{0}$ ditolak dan $\mathrm{H}_{1}$ diterima. Dengan demikian ada pengaruh model pembelajaran inkuiri terbimbing dan model pembelajaran discovery learning terhadap motivasi belajar peserta didik. Nilai ratarata motivasi belajar peserta didik yang dibelajarkan dengan model inkuiri terbimbing adalah 81,48 sedangkan model pembelajaran discovery learning adalah 85,48 . Hasil tersebut diperoleh bahwa ratarata motivasi belajar peserta didik yang dibelajarkan dengan model pembelajaran discovery learning lebih tinggi dibandingkan dengan model pembelajaran inkuiri terbimbing. Hal ini juga terlihat dari nilai median yang terpaut cukup jauh.

Penelitian ini sejalan dengan penelitian yang dilakukan Dewi, dkk (2015) menyatakan bahwa terdapat perbedaan peningkatan motivasi belajar IPA peserta didik yang dibelajarkan dengan menggunakan model pembelajaran discovery learning. Selain itu, hasil penelitian yang diperoleh Ginanjar (2015) yang menyatakan bahwa model pembelajaran berpengaruh terhadap motivasi belajar peserta didik. 


\section{c. Pengaruh Kemampuan Awal Tinggi dan Rendah terhadap Pemahaman Konsep Peserta Didik}

Berdasarkan pada hasil analisis inferensial diperoleh nilai signifikansi $0,000<\alpha$, yang berarti bahwa $\mathrm{H}_{0}$ ditolak dan $\mathrm{H}_{1}$ diterima. Dengan demikian terdapat perbedaan pemahamn konsep peserta didik yang memiliki kemampuan awal tinggi dan rendah. Adanya perbedaan pemahaman konsep menunjukkan bahwa ada pengaruh kemampuan awal terhadap pemahaman konsep peserta didik. Nilai rata-rata pemahaman konsep peserta didik yang memiliki kemampuan awal tinggi adalah 86,00 sedangkan kemampuan awal rendah adalah 70,19. Hasil tersebut diperoleh bahwa rata-rata pemahaman konsep peserta didik yang memiliki kemampuan awal tinggi lebih tinggi dibandingkan dengan kemampuan awal rendah. Hal ini disebabkan karena peserta didik dengan kemampuan awal tinggi memiliki pemahaman konsep yang lebih baik dibandingkan dengan kemampuan awal rendah. Dengan demikian, peserta didik yang memiliki kemampuan awal tinggi lebih siap dalam mengikuti pembelajaran daripada kemampuan awal rendah karena mereka sudah memiliki pengetahuan prasyarat yang memadai untuk mempelajari materi selanjutnya, yaitu materi larutan elektrolit dan nonelektrolit. Dalam materi ini, peserta didik harus menguasai materi sebelumnya yaitu klasifikasi materi, ikatan kimia dan stoikiometri sehingga memudahkan peserta didik untuk mengikuti pelajaran materi larutan elektrolit dan nonelektrolit.

Penelitian yang relevan dengan hal di atas yang dilakukan Laratu, dkk (2016) menyatakan bahwa kemampuan awal peserta didik berpengaruh secara signifikan terhadap pemahaman konsep. Selain itu, hasil penelitian yang dilakukan Husnaeni (2015) menyatakan bahwa ada pengaruh kemampuan awal terhadap pemahaman konsep peserta didik.

\section{d. Pengaruh Kemampuan Awal Tinggi dan Rendah terhadap Motivasi Belajar Peserta Didik}

Berdasarkan pada hasil analisis inferensial diperoleh nilai signifikansi $0,023<\alpha$, yang berarti bahwa $\mathrm{H}_{0}$ ditolak dan $\mathrm{H}_{1}$ diterima. Dengan demikian terdapat perbedaan motivasi belajar peserta didik yang memiliki kemampuan awal tinggi dan rendah. Adanya perbedaan motivasi belajar peserta didik menunjukkan bahwa ada pengaruh kemampuan awal terhadap motivasi peserta belajar didik. Nilai ratarata motivasi belajar peserta didik yang memiliki kemampuan awal tinggi adalah 86,53, sedangkan kemampuan awal rendah adalah 81,61. Hasil tersebut diperoleh bahwa rata-rata motivasi belajar peserta didik yang memiliki kemampuan awal tinggi lebih tinggi dibandingkan dengan kemampuan awal rendah.

Perbedaan rata-rata hasil motivasi belajar ini terjadi karena setiap individu mempunyai karasteristik yang berbedabeda dalam menerima dan merespon, mengolah informasi yang diberikan oleh guru sesuai dengan tingkat kemampuan awalnya. Dengan kemampuan awal yang tinggi memudahkan peserta didik terlibat secara aktif dalam proses pembelajaran melalui percobaan/eksprimen atau kajian literatur, sehingga membangkitkan motivasi belajarnya. Sardiman (2000) berpendapat bahwa peserta didik yang memiliki kemampuan awal yang tinggi memiliki motivasi yang besar dalam belajar dan cenderung aktif bertanya serta memiliki rasa ingin tahu yang lebih tinggi, sehingga lebih potensial berkembang kemampuan berpikirnya. Sebaliknya peserta didik yang mempunyai kemampuan awal rendah cenderung memiliki motivasi tidak setinggi peserta didik yang berkemampuan awal tinggi, salah satu contoh ditunjukkannya sikap masa bodoh dan sulit berkonsentrasi sepenuhnya pada materi yang dibelajarkan di kelas, terbukti tidak sedikit peseta didik yang mengobrol sendiri atau melakukan 
kegiatan yang tidak ada hubungannya dengan pelajaran.

Penelitian yang relevan dengan hal di atas, Rizkiana, dkk (2016) menyatakan bahwa peserta didik dengan kemampuan awal tinggi memiliki motivasi belajar yang lebih baik dibandingkan peserta didik dengan kemampuan awal rendah. Pengaruh mengenai kemampuan awal terhadap motivasi belajar juga diteliti oleh Lin, dkk (2011). Hasil penelitian tersebut menunjukkan bahwa kemampuan awal yang baik dapat membantu peserta didik memperoleh motivasi belajar yang baik pula.

\section{e. Interaksi antara Model Pembelajaran dan Kemampuan Awal terhadap Pemahaman Konsep Peserta Didik}

Berdasarkan pada hasil analisis inferensial diperoleh nilai signifikansi $0,608>\alpha$, yang berarti bahwa $\mathrm{H}_{0}$ diterima dan $\mathrm{H}_{1}$ ditolak. Dengan demikian tidak ada interaksi antara model pembelajaran inkuiri terbimbing dan model pembelajaran discovery learning dengan peserta didik yang memiliki kemampuan awal tinggi dan rendah dalam mempengaruhi pemahaman konsep peserta didik materi pokok larutan elektrolit dan nonelektrolit di kelas X SMA Negeri 1 Maniangpajo.

Nilai rata-rata pemahaman konsep peserta didik yang memiliki kemampuan awal tinggi pada model pembelajaran inkuiri terbimbing yaitu 83,20 dan pada model pembelajaran discovery learning yaitu 89,11, hasil ini memperlihatkan bahwa peserta didik yang memiliki kemampuan tinggi akan mendapatkan pemahaman konsep yang lebih tinggi pula.

Penelitian yang relevan dengan hal tersebut yang dilakukan Laratu, dkk (2016) menyatakan bahwa tidak terdapat interaksi antara model pembelajaran dan kemampuan awal terhadap pemahaman konsep.
f. Interaksi
antara
Model
Pembelajaran

\section{Awal terhadap Motivasi Belajar Peserta Didik}

Berdasarkan pada hasil analisis inferensial diperoleh nilai signifikansi $0,677>\alpha$, yang berarti bahwa $\mathrm{H}_{0}$ diterima dan $\mathrm{H}_{1}$ ditolak. Dengan demikian tidak ada interaksi antara model pembelajaran inkuiri terbimbing dan model pembelajaran discovery learning dengan peserta didik yang memiliki kemampuan awal tinggi dan rendah dalam mempengaruhi motivasi belajar peserta didik.

Penelitian ini menunjukkan bahwa antara model pembelajaran dan kemampuan awal peserta didik tidak saling mempengaruhi. Hal ini terjadi karena model pembelajaran inkuiri terbimbing dan model pembelajaran discovery learning yang digunakan memberikan kesempatan kepada peserta didik untuk lebih aktif dan mandiri dalam proses pembelajaran, sehingga peserta didik memiliki kebebasan mengembangkan aktivitas dalam menemukan konsep, mengidentifikasi dan memecahkan masalah yang akan membuat peserta didik bekerja aktif dalam kelompok dan akan meningkatkan motivasi belajar peserta didik pada masing-masing kemampuan awalnya. Hal ini berarti, model pembelajaran dan kemampuan awal tidak berpengaruh secara signifikan terhadap motivasi belajar peserta didik. Dengan demikian, tidak ada kontribusi secara bersama-sama yang dapat disumbangkan antara model pembelajaran dengan kemampuan awal untuk meningkatkan motivasi belajar peserta didik. Penelitian yang relevan dengan hal tersebut yang dilakukan Rizkiana, dkk (2016) menyatakan bahwa tidak ada interaksi antara model pembelajaran dan kemampuan awal terhadap motivasi belajar peserta didik.

\section{KESIMPULAN}

Berdasarkan hasil penelitian dan pembahasan yang dikaitkan dengan hipotesis dalam penelitian ini, maka dapat disimpulkan bahwa: 
1. Ada pengaruh model pembelajaran inkuiri terbimbing dan model pembelajaran discovery learning terhadap pemahaman konsep peserta didik.

2. Ada pengaruh model pembelajaran inkuiri terbimbing dan model pembelajaran discovery learning terhadap motivai belajar peserta didik.

3. Ada pengaruh kemampuan awal tinggi dan rendah terhadap pemahaman konsep peserta didik. Peserta didik yang memiliki kemampuan awal tinggi dan rendah memiliki pemahaman konsep yang baik.

4. Ada pengaruh kemampuan awal tinggi dan rendah terhadap motivasi belajar peserta didik. Peserta didik yang memiliki kemampuan awal tinggi dan rendah memiliki motivasi belajar yang baik.

5. Tidak ada interaksi antara model pembelajaran dan kemampuan awal terhadap pemahaman konsep peserta didik.

6. Tidak ada interaksi antara model pembelajaran dan kemampuan awal terhadap motivasi belajar peserta didik

\section{DAFTAR PUSTAKA}

Adesoji, Francis A. 2008. Students' Ability Levels and Effectiveness of Problem-Solving Instructional Strategy. J. Soc. Sci., 17(1): 5-8.

Astuti, Siwi Puji. 2015. Pengaruh Kemampuan Awal Dan Minat Belajar Terhadap Prestasi Belajar Fisika. Jurnal Formatif 5(1): 68-75.

Dahar, R.W. 2011. Teori-teori Belajar dan Pembelajaran. Jakarta: Erlangga.

Dewi, Ni Md. Sintya Novita., Jampel, I Nym., \& Sudarma, I Km. 2015. Pengaruh Model Discovery Learning Terhadap Motivasi Belajar Ipa Siswa Kelas IV Gugus I Kecamatan Jembrana. e-Journal PGSD Universitas Pendidikan Ganesha Jurusan PGSD Volume: 3 No: 1 Tahun 2015
Djamarah, Syaiful Bahri. 2000. Strategi Belajar Mengajar. Jakarta: Rineka Cipta.

Ginanjar., Agi. 2015. Pengaruh Metode Inkuiri terhadap Motivasi Belajar Siswa SMP. Jurnal Kependidikan, Volume 45, Nomor 2, November 2015, Halaman 123-129.

Herawati, Rosita Fitri., Mulyani, Sri., \& Redjeki, Tri. 2013. Pembelajaran Kimia Berbasis Multiple Representasi Ditinjau Dari Kemampuan Awal Terhadap Prestasi Belajar Laju Reaksi Siswa SMA Negeri I Karanganyar Tahun Pelajaran 2011/2012. Jurnal Pendidikan Kimia (JPK), Vol. 2 No. 2 Tahun 2013 Universitas Sebelas Maret Program Studi Pendidikan Kimia.

Husnaeni. 2015. Pengaruh Model Pembelajaran dan Kemampuan Awal Terhadap Kemampuan Berpikir Kritis dan Pemahaman Konsep Peserta Didik Kelas X IPA SMA Negeri 22 Makassar (Studi Pada Materi Pokok Larutan Elektrolit dan Nonelektrolit). Thesis. Tidak Diterbitkan.

Jacobsen, D.A., Eggen, P., Kauchak, D. 2009. Methods for Teaching. Terj. Sri Mulyantini Soetjipto. Yogyakarta: Pustaka Pelajar.

Joyce \& Weil. 2002. Model of Teaching. Boston: Allyn and Bacon.

Kemendikbud. 2014. Materi Pelatihan Guru Implementasi Kurikulum 2013. Jakarta: Kementrian Pendidikan dan Kebudayaan.

Laratu, Wahyuni N., Darsikin. \& Wahyono, Unggul. 2016. Pengaruh Model Pembelajaran Kooperatif Tipe STAD Berbasis Media Animasi Dan Kemampuan Awal Terhadap Pemahaman Konsep Listrik Dinamis Siswa SMA Negeri 8 Palu. e-Jurnal Mitra Sains, Volume 4 Nomor 2, April 2016 hlm 78-85.

Lin, Y.C., Lin, Y.T. \& Huang, Y.M. 2011. Development of a Diagnostic System 
Using a Testing-based Approach for Strengthening Student Prior Knowledge. Computer \& Education, 57: 1557-1570.

Nashar. 2004. Peranan Motivasi dan Kemampuan Awal dalam Kegiatan Pembelajaran. Jakarta: Delia Press.

Nuh, Mohammad. 2014. Kualitas Pendidikan Ditentukan Oleh Guru Dan Kurikulum Yang Berkualitas. http://www.paudni.kemdikbud.go.id/ berita/ 309.html.

Oghenevwedw, O. E. 2010. Effect od Discovery and Inquiry Approaches in Teaching and Learning of Biology on Secondary School Student's. journal of Research in Education Nigeria, 1(2) 30-39.

Rahman, R. dan Maarif, Samsul. 2014. Pengaruh Penggunaan Metode Discovery terhadap Kemampuan Analogi Matematis Siswa SMK AlIkhlas Pamaciran Kabupaten Ciamis Jawa Barat. Jurnal Ilmiah Program Studi Matematika STKIP Bandung, 3(1):33-55

Rizkiana, Fitria., Dasna, I Wayan. \& Marfu'ah, Siti. 2016. Pengaruh Praktikum dan Demonstrasi Dalam Pembelajaran Inkuiri Terbimbing terhadap Motivasi Belajar Siswa pada Materi Asam Basa Ditinjau dari Kemampuan Awal. Jurnal Pendidikan: Teori, Penelitian, dan Pengembangan Volume: 1 Nomor: 3 Bulan Maret Tahun 2016 Halaman: 354-3.

Sanjaya, W. 2010. Strategi Pembelajaran Berorientasi Standar Proses Pendidikan. Jakarta: Kencana Prenada Media Group.

Sardiman. 2000. Interaksi dan Motivasi Belajar Mengajar. Jakarta: PT Grafindo Persada.

Sochibin, A., Indah, D.W., dan Indriani. 2009. Penerapan Model Pembelajaran Inkuiri Terpimpin Untuk Peningkatan Pemahaman Dan Keterampilan Berpikir Kritis Siswa
SD. Jurnal Pendidikan Fisika Indonesia 5 (2009): 96-101.

Sudjana, Nana. 2011. Panduan Aplikasi Teori-Teori Belajar Mengajar. Bandung: Remaja Rosdakarya.

Supriyanto, Bambang. 2014. Penerapan Discovery Learning Untuk Meningkatkan Hasil Belajar Peserta didik Kelas VI B Mata Pelajaran Matematika Pokok Bahasan Keliling dan Luas Lingkaran Di SDN Tanggul Wetan 02 Kecamatan Tanggul Kabupaten Jember. Pancaran, Vol. 3, No. 2, hal 165174.

Syahputri, Ayu dan Derlina. 2016. Pengaruh Model Pembelajaran Discovery Learning terhadap Hasil Belajar Siswa Kelas Xi Semester Genap pada Materi Pokok Fluida Dinamis di SMA N 1 Stabat T.P 2014/2015. Jurnal Inpafi Vol. 4, No. 4, Nop 2016.

Uno, Hamzah B. 2010. Desain Pembelajaran. Bandung: MQS Pubhlishing.

Yulianingsih, U. \& Hadisaputro, S. 2013. Keefektifan Pendekatan Student Centered Learning dengan Inkuiri Terbimbing untuk Meningkatkan Hasil Belajar. Jurnal Inovasi Pendidikan Kimia, 2(2): 1-7. 